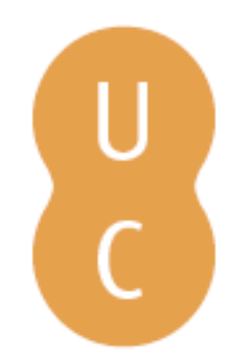

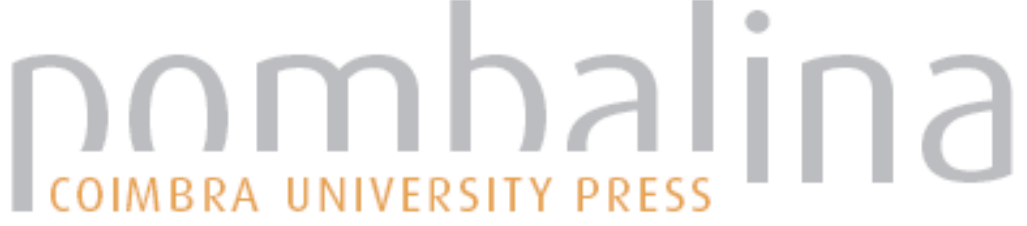

\section{Na aurora do conhecimento: do tumulto à pacificação}
Autor(es): $\quad$ Medeiros, Walter de Sousa
Publicado por: Centro de Estudos Clássicos e Humanísticos
URL
persistente:
URI:http://hdl.handle.net/10316.2/39243
DOI:
DOI:http://dx.doi.org/10.14195/978-989-26-1229-4_1

Accessed : $\quad$ 26-Apr-2023 12:29:05

A navegação consulta e descarregamento dos títulos inseridos nas Bibliotecas Digitais UC Digitalis, UC Pombalina e UC Impactum, pressupõem a aceitação plena e sem reservas dos Termos e Condições de Uso destas Bibliotecas Digitais, disponíveis em https://digitalis.uc.pt/pt-pt/termos.

Conforme exposto nos referidos Termos e Condições de Uso, o descarregamento de títulos de acesso restrito requer uma licença válida de autorização devendo o utilizador aceder ao(s) documento(s) a partir de um endereço de IP da instituição detentora da supramencionada licença.

Ao utilizador é apenas permitido o descarregamento para uso pessoal, pelo que o emprego do(s) título(s) descarregado(s) para outro fim, designadamente comercial, carece de autorização do respetivo autor ou editor da obra.

Na medida em que todas as obras da UC Digitalis se encontram protegidas pelo Código do Direito de Autor e Direitos Conexos e demais legislação aplicável, toda a cópia, parcial ou total, deste documento, nos casos em que é legalmente admitida, deverá conter ou fazer-se acompanhar por este aviso.

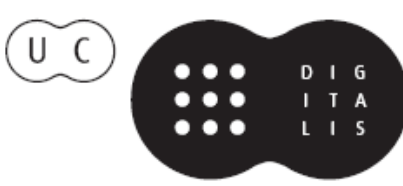


FRANCISCO DE OLIVEIRA

PAOLO FEDELI

DELFIM LEÃO

Coordenadores

\section{- ROMANCE ANTIGO ORIGENS DE UM GÉNERO LITERÁRIO}

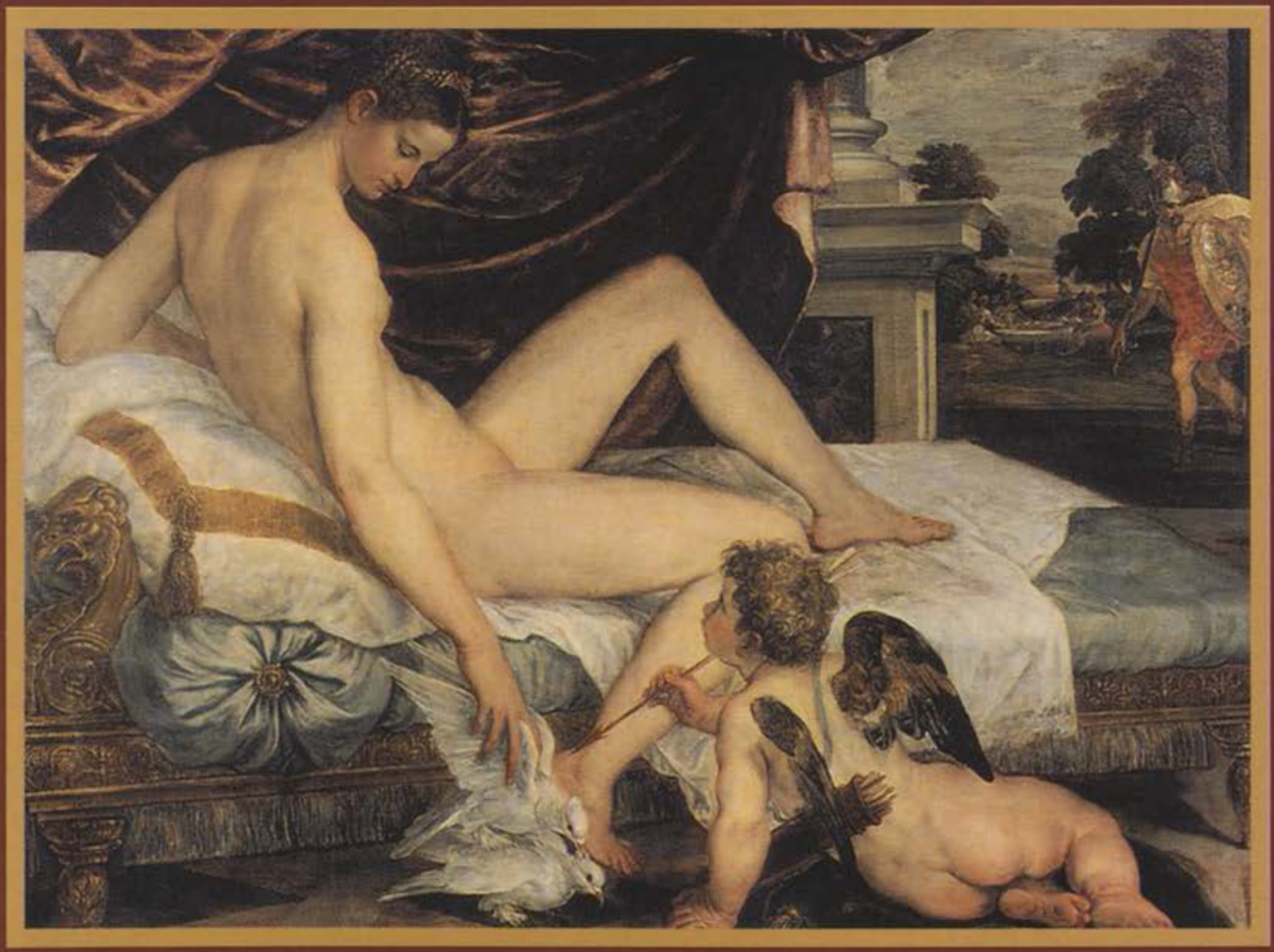

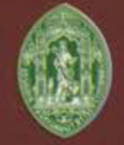

Universidade de Coimbra

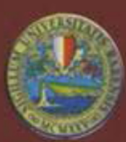

Università degli Studi di Bari

COIMBRA

2005 


\title{
NA AURORA DO CONHECIMENTO: DO TUMULTO À PACIFICAÇÃO
}

\author{
WALTER DE SOUSA MEDEIROS \\ Universidade de Coimbra
}

\begin{abstract}
Plot and objectives of the two remaining Latin novels: Petronius' Satyricon and Apuleius' Asimus Aureus sive Metamorphoseon libri XI.
\end{abstract}

Os dois romances podiam começar - não começam — no veludo do Mediterrâneo, sob o lírio rubro do sol, a esmeralda dos campos, a lua cavalgante o seu corcel de nuvens rarefeitas ou orientais. Mas o lume ofuscante de uma praça (diriam os cínicos) esconde as vielas lôbregas onde o silêncio coalha ou um corpo estertora na agonia do terror.

Os dois romances podiam começar - não começam - na deliquescência ou no brilho das vestes que as envolvem: Massília, Mónaco, a Campania felix, Crotona, Hípata, Corinto, sabe-se lá quantas mais. Uma urbs Graeca é pouco - não dá para sonhar. E já pensaram no nome dos anti-heróis principais? Encólpio lembra o aconchego do ventre materno, enquanto, cá fora, há lugar para sofrer, desvairar, e hora de morrer. Lúcio, ao invés, é menino ditoso da Fortuna, nasceu na cidade do Sol; e o seu mal é buscar as trevas. Precisam ambos de conhecimento (terrestre, celeste), para alcançarem a Paz.

Os dois romances podiam começar — não começam — no gáudio da esperança, porque toda a história é forjada de acertos e desacertos, de encontros e desencontros, onde amigos e opositores flutuam, mergulham, se afundam, à vezes têm a dita de emergir e sobreviver. Mas, quando emergem, quando sobrevivem, pouca história fica por contar: sobre os desamores da existência paira o arco-íris da felicidade. E Petrónio e Apuleio têm muito para contar, porque a triaga do conhecimento é longa de absorver. 
Os dois romances começam (e prosseguem) no fadário da insensatez - que importa dissipar para crescer. Encólpio (pelo que diz, pelo que se vê) foi bode expiatório, ladrão, adúltero, assassino, profanador, impotente. Por desgraça, amou um efebo catavento e uma mulher deslumbrante que the dava o corpo de sonho e ele não conseguia possuir. Mas Encólpio tem, no acervo de crimes e de fraquezas, um quid de inocência, uma esperança desesperada de melhorar. Por isso Mercúrio lhe há-de valer, Mercúrio the restituirá a virilidade. Para que possa viver mais aventuras e porventura ser feliz. Se o seu criador, Petrónio, acreditava na felicidade - não sabemos. Em canções ligeiras e versos fáceis, acreditava: e ao som deles quis morrer. Como se aquela despedida bizarra fosse a vingança póstuma do mundo em que vivera.

Lúcio, filho da Luz, aluno da Luz, queria experimentar outra escola - a escola das trevas. Queria aprender a magia, ser capaz de se transformar, ou transformar, em animal, árvore, rio ou pedra. Fez ele mesmo a experiência: e da ave que se libra no céu nasceu um animal que se espoja na terra, tem longas orelhas para escutar e sofrer na pele a tortura das pancadas e das ameaças de morte. Tudo em nome da curiosidade. Uma curiosidade malsã que the saiu cara, como a Psique. A jovem amava o Amor, e o Amor quase o perdeu, quando incauta o queimou com um pingo de cera traiçoeira. E condenada foi Psique, como Lúcio, ao seu cilício de tormentos. Até que o Amor voltou e a salvou da morte e the deu a imortalidade e uma filha, Voluptas, a Alegria e o Prazer, fraternos da Graça sempiterna. Também de Lúcio se amerceou a deusa Ísis, the restituiu, graças a uma coroa de rosas, a face humana; e the concedeu o Bem supremo que é, na terra, o privilégio de raros.

Os dois romances terminam com os olhos da esperança. Faltava aos anti-heróis o dom do conhecimento: dos outros e de si mesmos. Um dom tão alto, tão exaltante que, para alguns, se alcança apenas no topo do calvário. Com a auréola da Paz que a felicidade é chamada a consagrar. 